The Australian Journal of

\title{
Rehabilitation Counselling
}

Volume 2・Number 2・1996

A Publication of the Australian Society of Rehabilitation Counsellors 


\section{EDITOR}

Nicholas J. Buys Ph.D.

Griffith University, Queensland, Australia

\section{ASSOCIATE EDITOR}

Herbert C. Biggs B.A.(Hons)

Southern Cross University, New South Wales

\section{CONSULTING EDITORS}

Henry B. Andrews Ed.D.

Curtin University of Technology, Western Australia

Roy I. Brown Ph.D.

Flinders University, South Australia

Laurie R. Buys Ph.D.

Queensland University of Technology, Queensland

Fong Chan Ph.D.

University of Wisconsin-Madison, Wisconsin, U.S.A.

Lesley Chenoweth M.Soc.Wk.

Griffith University, Queensland

Darien Chinnery Ph.D.

University of Sydney, New South Wales

William Crimando Ph.D.

Southern Illinois University, Illinois, U.S.A.

Ross Crisp M.Soc. Sci.

Commonwealth Rehabilitation Service, Victoria

Marita M. Danek Ph.D.

Gallaudet University, Washington D.C., U.S.A.

Ross A. Flett Ph.D.

Massey University, New Zealand

Juliet H. Fried Ed.D.

University of Northern Colorado, Colorado, U.S.A.
Lindsay Gething Ph.D.

University of Sydney, New South Wales

Di Gursansky M.P.A.

University of South Australia, South Australia

Trevor Hawkins M.S.

University of Sydney, New South Wales

David B. Hershenson Ph.D.

University of Maryland, Maryland, U.S.A.

Paul Leung Ph.D.

Deakin University, Victoria

Nigel V. Marsh Ph.D.

University of Waikato, New Zealand

Diane C. Munrowd M.A.

WorkCover, Western Australia

Gregory C. Murphy M.A.

La Trobe University, Victoria

Dimity Peter Ph.D.

Flinders University, South Australia

Andrew G. Remenyi M.A.

La Trobe University, Victoria

Vivienne Riches M.A. (Hons)

Macquarie University, New South Wales

Jon Russell Ph.D.

La Trabe University, Victoria

Martha Lentz Walker Ed.D.

Kent State University, Ohio, U.S.A.

\section{EDITORIAL STAFF}

ASORC LIAISON \& EDITORIAL ASSISTANT

Michael Hancock

SUBSCRIPTIONS MANAGER

Andrea Kenafake

Published by the Australian Society of Rehabilitation Counsellors, GPO Box 1978, Brisbane Qld. 4001

Subscription Rates: Individual: $\mathrm{A} \$ 24.00$; Institutional: $\mathrm{A} \$ 46.00$. Overseas Airmail (Extra $\mathrm{A} \$ 10.00$ to above). Single copies (if available) are pro rata volume rate. Members of The Australian Society of Rehabilitation Counsellors receive the Journal as part of their annual dues.

Advertising Rates: The Australian Journal of Rehabilitation Counselling is a non-for-profit publication that is circulated to approximately 700 persons, including all members of the Australian Society of Rehabilitation Counsellors. The Journal will accept advertising that may be of interest to its readers. Rates are as follows:

Full page: $\$ 250$; Half page: \$175; Quarter page: \$125. Discounts are available for multiple advertisements. All advertisements must be submitted camera-ready. 


\section{The Australian Journal of Rehabilitation Counselling Volume 2・ Number 2・1996}

\section{EDITORIAL}

The Woodhouse Report 22 years on

Nicholas J. Buys

\section{ARTICLES}

Expansion Rehabilitation: An Empowering Conceptual

Framework for Rehabilitation following Acquired Disability

Rex Newsome and Elizabeth Kendall

The Roles, Functions and Effectiveness of Treating Doctors

in the Management of Occupational Injury: Perceptions of Key Stakeholders

Dianna T. Kenny

Cognitive-behavioural Therapies: Research and Applications

in Counselling People with Physical Disabilities

Elias Mpofu, Kenneth R. Thomas and Fong Chan

Transition From School to Adult Life in the United States:

Issues, Practices, and Recommendations

Jean P. Lehmann, Laurie R. Buys and Raymond E. Nelson

Is Compensation Bad for your Back?

128

Grant Duncan

\section{PRINT AND MEDIA REVIEW}

Herbert Biggs, Associate Editor

Developing Leisure Identities: A Pilot Project 